https://doi.org/10.18485/iipe_euchanges.2021.ch15

\title{
THE BELARUSIAN ISSUE IN EUROPEAN AFFAIRS
}

\begin{abstract}
Vladimir TRAPARA ${ }^{1}$
Abstract: Belarus - an East European country, but actually located in the geographical centre of Europe - in 2020 topped the agenda of political affairs on the continent by facing the biggest political crisis since its independence, triggered by President Lukashenko's election fraud and massive citizens' protests that followed. Though domestic in nature, this crisis has huge implications for broader European affairs, due to the geopolitical position of Belarus between Russia and the political West. However, the explanation of the essence of the Belarusian issue which culminated in the mentioned presidential crisis - which is the central research goal in this paper - cannot rest solely on issues of geopolitics and authoritarianism. It requires a deeper historical analysis of the identity of the state of Belarus and Belarusians as a nation, as well as consideration of the role of Lukashenko in this context. The main thesis of the paper is that Belarus has an unusually weak and unfinished national identity, close to Russia, but marked by a long period of detachment from it. The secret of Lukashenko's longevity in power is a congruence of his political philosophy with this identity and a wider obsession of Belarusians with political stability and personal well-being. Namely, his failure to deliver these values led his political fate to a deadend in 2020 and stressed the significance of the Belarusian issue for wider European affairs. Yet, Lukashenko's possible resignation does not bring a solution because the weak identity of Belarusians would still make them victims of the ongoing European geopolitical divide.

Keywords: Belarus, Lukashenko, 2020 presidential crisis, national identity, geopolitics, authoritarianism, Russia-Western relations.
\end{abstract}

\footnotetext{
${ }^{1}$ Research Fellow, Institute of International Politics and Economics, Belgrade, Serbia. E-mail: vtrapara@diplomacy.bg.ac.rs

The paper presents findings of a study developed as a part of the research project "Serbia and challenges in international relations in 2021", financed by the Ministry of Education, Science, and Technological Development of the Republic of Serbia, and conducted by Institute of International Politics and Economics, Belgrade.
} 


\section{INTRODUCTION}

Belarus, a 10-million country located in East Europe, was not the main focus of many international relations researchers since its independence in 1991. For comparison, neighbouring Ukraine has always attracted much greater attention. Some facts about Belarus are widely known and usually taken for granted, without further examination, such as: that it is 'the last European dictatorship' ruled by its strongman Lukashenko since 1994; that it is the most loyal ally of Russia, with which it forms a monolith antiWestern geopolitical bloc. The geopolitical position of Belarus between Russia and the West is a commonsense reason why the West has always been loud in criticizing its authoritarianism, while being mostly silent when it comes to even more autocratic regimes from the post-Soviet space, such as those in Azerbaijan and Central-Asian states (Ioffe, 2014, p. 87). However, the Belarusian issue in European affairs is too complex to be reduced only to geopolitics, or the questions of autocracy/democracy. Recent events, related to the presidential crisis of 2020, brought this issue to the top of the international relations agenda. This paper aims to explain how and why it happened, which requires a deeper analysis that would go to the issue's very roots - by answering the questions about how the state of Belarus came to exist as a separate entity in the first place, and how Belarusians think about themselves and the world? This is the only context in which it would be possible to consider the role of Lukashenko and its quarter century-long rule, as well as the seemingly dead-end position in which he found himself after the last elections. That said, the structure of the rest of the paper can be easily revealed: firstly, the identity of Belarus and Belarusians is examined using the historical method; secondly, the phenomenon of Lukashenko is put into this context; thirdly, the presidential crisis of 2020 is analysed starting with what previously was determined, which leads us to the essence of the Belarusian issue and its prospects.

\section{WHAT IS BELARUS AND WHO ARE BELARUSIANS?}

Pre-history of the formation of contemporary Belarusian statehood and national identity leads us to the early medieval period and the Principality of Polotsk, which - especially during the reign of Rogvolod ( $10^{\text {th }}$ century) and Vseslav (11 $1^{\text {th }}$ century) - managed to achieve a significant degree of prosperity and autonomy inside what was then known as Kievan Rus' (the cradle of modern Russian, Ukrainian and Belarusian peoples, as well as their respective states) (Wilson, 2011, pp. 3-10). The term Belarus' (literally 'White 
Russia') originated in this period, with two possible explanations for such etymology: people of Polotsk received Christianity in the $10^{\text {th }}$ century (together with most of the rest of Kievan Rus'), unlike Baltic tribes in 'Black Russia' (the territory around contemporary Belarus-Lithuania border); Polotsk remained outside the reach of the Mongol Golden Horde after it conquered Kiev in 1240 (Wilson, 2011, pp. 19-20). However, modern Belarusian nationalists failed to establish a Belarusian national identity on the Polotskian myth; it was rather used in the $19^{\text {th }}$ century by the Russian Slavophiles as proof that Western parts of the Russian Empire were Orthodox at the moment of the Great Schism of 1054 (Wilson, 2011, p. 17).

Contemporary Belarusian nationalism was, in fact, far more influenced by a five century-long period during which the complete territory of what is today Belarus rested within the Grand Duchy of Lithuania (since 1569 a part of the Polish-Lithuanian Commonwealth). This was the time when Belarus and Belarusians were cut off from Russia both politically (belonging to a separate political entity which even fought several wars against the Grand Duchy of Moscow and later Russian Empire) and culturally/religiously (residing inside a Catholic-dominated state since Grand Duke Jogaila's conversion to Western Christianity in 1386/1387, while most of Belarusians - who were then, alongside with Ukrainians, called Ruthenians - accepted the Union of Brest from 1596) (Wilson, 2011, pp. 18-27, 33-38, 42-49; Marples, 2012, pp. 19-20). From Nasha Nyiva ('Our Field') magazine at the beginning of the $20^{\text {th }}$ century to the Belarusian People's Front (BNF) at its end, the Belarusian national movement claimed that the Grand Duchy was actually Belarus, citing peaceful incorporation of the Belarusian lands into a new state, numerical advantage of the ethnic and linguistic Belarusian population over nominal Lithuanian, and common use of the Belarusian language in state affairs (Wilson, 2011, pp. 25, 27, 83-84, 141). The Pahonia emblem (a horseman wielding his sword above his head), used as a coat of arms of Belarus on three occasions of its independence from Russia in the $20^{\text {th }}$ century, but also (alongside with white-red-white flag that accompanied it) by anti-Lukashenko protesters - is actually the Grand Duchy's (the contemporary state of Lithuania also uses its variant).

After it entirely absorbed the territory of Belarus in three partitions of the Polish-Lithuanian Commonwealth in the late $18^{\text {th }}$ century, the Russian Empire did its best to prevent (or at least slow down) the process of Belarusian national awakening. It started with phased, but complete eradication of the Uniate Church from Belarusian soil (Wilson, 2011, pp. 58, 64). For comparison, Ukrainians remained Uniates in Galicia, which became 
a part of the Habsburg Empire, out of Russia's reach, and would serve as an epicentre of later Ukrainian nationalism (Trapara, 2020, pp. 166-167). ${ }^{2}$ St. Petersburg supported an alternative version of nationalism in the shape of 'West-Russism' which, although popularized the term Belarus, in fact, negated separate Belarusian identity (Wilson, 2011, pp. 69-76). Moreover, societal obstacles for the development of the authentic Belarusian national movement were numerous: fluid language, spoken mostly by the peasantry, low literacy, education and mass communication, absence of the middle class, the domination of minorities (mainly Jews and Poles) in the cities, etc (Wilson, 2011, pp. 85-87; Marples, 2012, p. 20; Ioffe, 2014, pp. 62-63). Nor was there anything similar to the Ukrainian Cossack myth to serve as the foundation for Orthodox national identity, but separated from the Russian (Wilson, 2011, pp. 62-63). Nevertheless, the contours of the Belarusian national movement started to appear at the crossing between the $19^{\text {th }}$ and $20^{\text {th }}$ century in several forms, among which the aforementioned Nasha Nyiva was the most prominent (Wilson, 2011, pp. 77-88). This process was firstly interrupted, but then in a perverted way stirred up by World War I.

During the war, German occupiers reluctantly supported the Belarusian national movement; after the Brest-Litovsk peace agreement with the Bolsheviks in March 1918, they did the same with the short-lived Belarusian People's Republic. The internal divisions of its leadership and later German defeat prevented this first-ever state under the name of Belarus and with white-red-white flag and Pahonia as national symbols from living longer (Wilson, 2011, pp. 91-96; Marples, 2012, pp. 22-25). Thus, the first real embodiment of the Belarusian national movement's aims actually became BSSR (Byelorussian Soviet Socialist Republic), created as one of the federal units of the Soviet Union after the Bolsheviks' victory in the civil war. In the first decade of its existence, the process of 'belarusization' - encouragement of the use of the Belarusian language in public communication and education - was stronger than ever before or later. Belarusian national identity was being formed 'from above', with the Communist ideological coating, and inside the broader Soviet political community (Wilson, 2011, pp. 96-105; Marples, 2012, pp. 25-29). Yet, this has also been short-lived already in the 30s, Stalin saw a separate Belarusian national identity as a 'bourgeois element' and a threat to the Soviet state, so he reversed the process of belarusization and purged most of the Belarusian intellectual elite

\footnotetext{
${ }^{2}$ It is interesting that Galicians, unlike Belarusians, did not accept the Union immediately, but resisted it for a century (Wilson, 2011, pp. 48-51).
} 
(Marples, 2012, pp. 29-32). World War II additionally compromised the Belarusian national movement (and its national symbols) because of its collaboration with the Nazis (Wilson, 2011, pp. 108-110; Marples, 2012, pp. 39-41). Moreover, a new myth appeared, which even more closely attached Belarusian identity to the broader Soviet one - that of Partisan movement liberation struggle, which was especially strong in the territory of Belarus (Wilson, 2011, pp. 110-115).

Namely, two members of the Partisan movement were the most prominent leaders of the Communist Party of Belarus (its official name during the Soviet period was Byelorussia) after the war: Kirill Mazurov (First Secretary from 1956 to 1965, then moved to a higher position in Moscow) and Piotr Masherov (1965-1980, when he died in a suspicious car accident). This was the time of fast industrial development of what used to be a rural society (Wilson, 2011, pp. 115-116; Marples, 2012, pp. 43-44, 46-47). Belarus even acquired international subjectivity with a seat at the United Nations, but its leadership never actually separated loyalty to their homeland from that to the Soviet Union; a new wave of russification was also on the rise during the Brezhnev years (Wilson, 2011, p. 117; Marples, 2011, pp. 45, 4950). This resulted in Belarus being probably the most 'Sovietized' of all Soviet republics during 'perestroika', with the majority of its citizens not wanting national independence (Wilson, 2011, pp. 142, 150). The independence, nevertheless, ensued. In fact, the decision to dismantle the Soviet Union was made on Belarusian territory, with Belavezha agreement, signed in December 1991 by the presidents of Russia and Ukraine, Yeltsin and Kravchuk, and the Chairman of Belarusian Supreme Soviet, moderate nationalist Stanislav Shushkevich (Wilson, 2011, pp. 152-153). The communists led by Vyacheslav Kebich supported Shushkevich, adopted the white-red-white flag and Pahonia as national symbols of a newly independent Belarus, as well as the law which made Belarusian the official language and degraded Russian to a 'language of inter-ethnic communication'. They did all this in order to appease opposition nationalists, seeing this as necessary for staying in power (Wilson, 2011, pp. 124, 148-149, 151-154; Marples, 2012, pp. 101-103, 109). However, they did not want to cut ties with Russia (actually, Yeltsin's Russia was the one to be more sceptical about the projects of integration), refused to perform 'shock therapy' transition, and hesitated with the adoption of a new constitution which would transform Belarus into a presidential republic (Wilson, 2011, pp. 150, 154-155, 159; Marples, 2012, pp. 64-68, 106-109). 
At the beginning of the $90 \mathrm{~s}$ of the $20^{\text {th }}$ century, Belarus for the first time became an independent and internationally recognized state under its real name. However, this independence was unwanted by most of its population, and its leaders were not ready for it - thus, it was yet another 'false start' in Belarusian 'start-stop' history, as Andrew Wilson suggests (Wilson, 2011, pp. 140-141; Marples, 2012, pp. 94-95). The bitter division in the leadership that erupted between Kebich and Shushkevich was certainly not helpful for nation-building (Marples, 2012, p. 105). The 'umbilical cord' with Russia was never cut (Ioffe, 2014, pp. 3-4). Those who favoured it were extreme nationalists represented by the Belarusian Popular Front led by Zianon Pazniak. ${ }^{3}$ Their views that Russia and the Soviet Union were actually barbaric occupiers who separated Belarus from the West, where it has belonged since the time of the Grand Duchy of Lithuania, were shared only by a minority of Belarusians (Wilson, 2011, pp. 137, 138, 141; Ioffe, 2014, p. 63). Nevertheless, Belarus was different from Russia in many ways, from its people mentality to the economic system it adopted in the post-Soviet period; also, due to its geographical position, it never had reason to doubt its 'Europeaness' (Ioffe, 2014, p. 76). It would be a paradox that the leader who at first negated the need for separate Belarusian national identity became the greatest nation-builder in the history of Belarus.

\section{THE LUKASHENKO PHENOMENON}

To remove Shushkevich from the post, Kebich co-opted his former rival on all-Soviet elections, Alexander Lukashenko. Lukashenko chaired the anticorruption commission, whose report was used against Shushkevich when the parliament finally brought him down in 1994 (Wilson, 2011, pp. 156158). However, this anti-corruption narrative gave Lukashenko an enormous rise in popularity during the next few months, after which he would sweep his opponents in the first and the last free and fair presidential elections in Belarus so far - the result of the second round was 80:14 percent against Kebich (Wilson, 2011, pp. 164-166; Marples, 2012, p. 118; Ioffe, 2014, pp. 127-131). Lukashenko was born in a village in Eastern Belarus and had a typical Soviet carrier - he served in the military as a border guard, and later assumed the position of a collective farm manager (Wilson, 2011, p.

\footnotetext{
${ }^{3}$ Pazniak firstly became known as the archaeologist who discovered mass graves of the victims of Stalin's purges in Kurapaty in the late 80s (Wilson, 2011, pp. 144145; Marples, 2012, pp. 86-89, 95-97).
} 
148; Marples, 2012, pp. 118-119; Ioffe, 2014, pp. 120-123). He became interested in politics during 'perestroika' and used the confusion in the elite and the people during the first two and a half post-independence years to get to the top (Wilson, 2011, pp. 159-163; Ioffe, 2014, pp. 123-127). After this, he did everything to make sure he would never come down again. In two referendums in 1995 and 1996, he gave his presidential function almost absolute prerogatives, including the ones in the legislative branch of power, and in 2004 removed the limit of consecutive presidential terms (Wilson, 2011, pp. 174-184, 207; Marples, 2012, pp. 122-127, 152-156; Ioffe, 2014, pp. 133-136). He systematically eradicated all checks and balances in the political system, after which he overwhelmingly won four more presidential terms - in 2001, 2006, 2010, and 2015. These elections were of course far from free or fair; but even if they were, Lukashenko would win them, at least in the second round, for he always kept his rating between 30 and 50 percent, far above any opposition politician - he would falsify the results up to 70 or 80 percent in order to show how dominant he was compared to any opposition (Wilson, 2011, pp. 198, 218-221, 233-235, 258; Ioffe, 2014, pp. 80, 144-147). How did he manage to sustain significant popular support for 25 years?

The key element of Lukashenko's success was the congruence of his economic policies with the mentality of the common Belarusian people. In the beginning, Lukashenko had an idea to liberalize the Belarusian economy, but quickly abandoned it when he saw the expected consequences (already experienced in neighbouring Russia and Ukraine) as a threat to his popularity (Wilson, 2011, pp. 169-170; Marples, 2012, pp. 69-71; Ioffe, 2014, p. 44). Instead, he went even further than his Communist predecessors in retaining state control over the economy and refusing mass privatization and the free market (Ioffe, 2014, pp. 26-27). His strategy was successful Belarus passed from a negative into positive GDP growth before Russia and Ukraine did, after which its economy constantly grew until 2014 (minimal growth was present even in 2009 when Belarusian neighbours had sharp decline due to the world economic crisis) (Ioffe, 2014, pp. 29-30). Moreover, although Belarus was certainly not as wealthy as Russia, its wealth was far more equally distributed among its citizens - there were no enormously rich oligarchs and the majority of poor people (Ioffe, 2014, pp. 12-13, 33). Lukashenko's Belarus had a decent education and health care system, and a very low level of criminality (Ioffe, 2014, pp. 33-37). Thus, this was a sort of paternalistic 'social contract' between Belarusian citizens and their president, in which Lukashenko was Batka (literally father) who provided well-being for his people, while they accepted his authoritarian behaviour in return (Ioffe, 2014, p. 177). To Lukashenko, power and authority were 
more precious than personal enrichment; to most Belarusians, the personal standard of living was far more valuable than democracy (Ioffe, 2014, pp. 52-53). Yet, democracy was not the only depreciated value in Belarus.

Lukashenko came to power as a Russophile and Soviet-nostalgic man who did not see the need for a separate Belarusian national identity. ${ }^{4}$ However, it was not only up to his personal feelings - he recognized that most of the Belarusian people shared his view and that the BNF's radical national project was not acceptable to them (Wilson, 2011, p. 139). Up to 70 percent of Belarusians used Russian as the language they normally spoke at home, not Belarusian (Wilson, 2011, p. 123). Thus, Lukashenko removed the existing law on languages and started restricting the use of the Belarusian language (during the first years of his reign, the number of schools and media in Belarusian dramatically fell). He also replaced state symbols (and even banned white-red-white flag and Pahonia) with a new flag and coat of arms, which were actually old BSSR symbols, but without Communist elements (Wilson, 2011, pp. 124-125, 174). And even before the end of the 90s, he completely eradicated the BNF (whom he considered fascists) from Belarusian political life (Wilson, 2011, pp. 171-172; Marples, 2012, pp. 137-138). From the imposition of the authoritarian system during the middle of the 90s onwards (at least until the most recent events), nationalists would be the ones to lead all anti-Lukashenko protests, a common feature of which would become namely these symbols. However (again until the most recent events), most Belarusians would still - in both symbolic and essential way - be much closer to Lukashenko's vision of national identity (weak and inseparable from the Russian, as it is) than to that of his nationalist opponents.

Yet it was not only Lukashenko's personal Russophilia and his Russianspeaking voters that drew Belarus closer to Russia. Enormous subsidies from Moscow, especially those in the form of discounted oil and gas prices, were essential if the Belarusian regime wanted to preserve the level of people's well-being on which it founded its own stability (Ioffe, 2014, pp. 46-48; Suzdaltsev, 2020, p. 69). Yet, there have been many ups and downs in Russia-Belarus relations. Institutional foundations of the integration between the two states were laid down in the late 90s, culminating with the creation of the Union State of Russia and Belarus. However, it was a single

${ }^{4}$ Allegedly, he was the only deputy in the Belarusian Supreme Soviet who voted against the Belavezha agreement, thus against the independence of Belarus (Marples, 2012, p. 119). 
state only in its name - it neither had state symbols, nor single currency, while both countries retained their sovereignty (Marples, 2012, pp. 171-182). It was Lukashenko, who at first was in favour of unification, hoping to become the president of the vast territory from Brest to Vladivostok; namely out of fear from this scenario, Yeltsin's Russia blocked further integration (Ioffe, 2014, pp. 138-139; Wilson, 2011, p. 173). After Putin came to power in Moscow, the tables turned: Lukashenko gave up on his dream to enter the Russian political scene and started to emphasise Belarusian sovereignty; Russia became the one who pushed for closer integration (Ioffe, 2014, p. 140). ${ }^{5}$ Lukashenko's relations with Moscow were good during most of the first decade of the $21^{\text {st }}$ century, when Russia strongly supported the survival of the Belarusian regime in the face of its growing isolation from the West, including sanctions; Belarus was successfully used as a testing ground for strategies against 'coloured revolutions' (Wilson, 2011, p. 212). Things started to complicate after the Russia-Georgia War in 2008.

Even before 2008, Russia and Belarus had some economic disagreements, starting with Lukashenko's refusal to treat Russian investors preferentially, and continuing with several energy crises, when Minsk always had to accept increases in oil and gas prices (Wilson, 2011, pp. 186, 200, 222). But Russia's intervention in Georgia and recognition of Abkhazia and South Ossetia presented Lukashenko with a prospect of similar violations of the sovereignty of Belarus and a threat to his own political survival if Moscow decided so. Thus, he started first to diversify his energy supplies (with oil shipments from Azerbaijan, Iran and Venezuela), economic (strengthening ties with China) and then political relations (Wilson, 2011, pp. 223; Ioffe, 2014, p. 49). Western countries soon realized that improvement in relations with 'the last European dictator' (as then US state secretary Condoleezza Rice called Lukashenko) could be geopolitically beneficial in the face of a new confrontation with Russia (Wilson, 2011, p. xi). Some sanctions were lifted and high-level contacts between Belarus and the EU and its members were renewed (Wilson, 2011, pp. 226-228; Ioffe, 2014, pp. 90-95). However, violence against opposition protesters in Minsk in late 2010 alienated the West again (Wilson, 2011, pp. 229-235; Ioffe, 2014, pp. 100-105). Moreover, the financial crisis that struck Belarus in 2011 showed Lukashenko how much he was dependent on Russia economically, but this settlement was quite temporary (Ioffe, 2014, pp. 41-44, 84-85).

${ }^{5}$ Putin wanted Belarus to join the Russian Federation, not as a single federal unit but each of its six regions separately (Ioffe, 2014, p. 149). 
The Ukraine crisis in 2014 was a more serious kind of threat. Russia's readiness to use force to annex the territory of its own and Belarus's East Slavic neighbour alarmed Lukashenko more than ever before, for it also opened the possibility of involving Belarus in a conflict between Russia and the West (Lanoszka, 2017, pp. 81-83; Astapenia and Balkunets, 2016, pp. 68 ). Yet, he has used this as an opportunity to actually improve the international position of his country and himself. He managed to act as a kind of mediator in the conflict, hosting the delegations of the Ukrainian government and pro-Russian rebels from Donetsk, but also to thaw his relations with the West once again, without abandoning the Russian vector as well. This was also the imperative for one additional reason - as a result of Western sanctions and decrease in oil prices, Russia's economy started to shrink together with its ability to subsidize Belarus, whose economy also fell in 2015 and 2016, for the first time in 20 years (Kuleszewicz, 2016, pp. 37-38). In order to extract more economic benefits from cooperation with the West (Belarus also started improving its ties with China), Lukashenko had to soften his authoritarianism at home, which proved successful in 2015, when he won yet another partly falsified elections, but sustained himself from the crackdown against opposition protesters, who were less numerous than before anyway (Crabtree et al., 2016, pp. 2-3). But he could not completely avoid Belarus's dependence on Russia, who was determined to keep Belarus in its sphere of influence. Lukashenko's 'sitting in two chairs' annoyed Moscow, while - due to the mentioned economic crisis in Russia it was less and less ready to give him money and getting nothing in return. So, during the second half of the last decade, Russia employed a twopronged strategy for disciplining Lukashenko: it started to support some opposition circles, and also lead a false-flag propaganda campaign against anti-Russian nationalism in Belarus, the actual goal of which was to provoke nationalists to act against Lukashenko and make his position more difficult; it presented Belarus with ultimatums to accept closer integration if it wanted further subsidies, knowing that Lukashenko's rating started to crumble because of the economic crisis (Leukavets, 2017, pp. 2-4; Klysinski, 2017, pp. 5-8; Nizhnikau and Moses, 2020, pp. 48, 57; Suzdaltsev, 2020, pp. 73-76).

Nevertheless, the Belarusian president is too experienced to retreat so easily. Ahead of new presidential elections, it seemed that he tamed Russian pressure by promising greater integration, but delaying concrete concessions - including the establishment of a permanent Russian military base on Belarusian soil - at least for some time (Suzdaltsev, 2020, pp. 75-76). On the other hand, he improved ties with the most powerful country in the West the United States, whose state secretary Mike Pompeo visited Belarus in 
February 2020, after which the US ambassador returned to Minsk and shipments of American oil to Belarus began (Nizhnikau and Moses, 2020, p. 49). However, Lukashenko's biggest success was probably achieved in the domestic arena, where he really managed to present himself as a greater defender of Belarusian sovereignty and nation-builder than nationalists could become. The majority of the Belarusian people still valued economic well-being and political stability more than democracy or becoming a Western nation that would turn against Russia - they saw very well what the price for this was in Ukraine (Kuleszewicz, 2016, p. 35; Wilson, 2016, p. 81). Winning yet another five-year presidential term in a similar fashion how he did it five times before was expected, and it would enable Lukashenko to provide himself with additional time to settle disputed things both internationally and domestically. Nevertheless, the achievements in Lukashenko's struggle against man-made challenges were soon annulled by the forces of nature, which brought the Belarusian issue to the fore of European affairs.

\section{WHAT DOES THE 2020 PRESIDENTIAL CRISIS BRING?}

When Pompeo visited Minsk, a new coronavirus was ravaging China and making its way into many other countries. But at that moment, no one expected the unprecedented state in which the whole world would find itself only a few weeks later - after the World Health Organization declared the pandemic on March 11. In order to halt the spread of a deadly disease called COVID-19, governments throughout Europe and the world started imposing harsh measures of social distancing on their citizens, including quarantines, curfews and lockdowns, which actually threatened to cause similar if not worse damage than the virus could, especially to the economy. Only a few countries chose a different approach, and one of them was Belarus. Lukashenko at first negated that the virus was so that dangerous to require any extraordinary measures, but it is also possible that he had calculated ahead of the elections that his popularity could fall should he impose restrictions on his people. His calculations were wrong.

On the contrary, afraid for their health and lives, the Belarusian people got an additional reason to feel as they were betrayed party in the social contract with Lukashenko (Racz et al., 2020, p. 2; Dobrinsky, 2020, pp. 9-10). The opposition used networks for helping doctors and patients which civil society started to form to mobilize its supporters (Zahorski, 2020, p. 2). Three potential presidential candidates came to the front: Viktor Babariko, the 
director of BelGazprom Bank; Sergey Tikhanovsky, blogger; and Valery Tsepkalo, a former diplomat. Independent polls showed that Babariko's rating was the greatest (around 50 percent) (Zahorski, 2020, p. 4). Lukashenko's regime did not stand idle in the face of this challenge. All three opposition candidates were banned from participating in the elections: Babariko and Tikhanovsky were arrested on fabricated charges, while Tsepkalo's signatures were declared void, after which he fled to Russia to escape arrest (Racz, 2020, p. 2; Zahorski, 2020, pp. 2-3). After Babariko's arrest, Sergey's wife Svetlana Tikhanovskaya entered the presidential race. The regime allowed her to compete, for it obviously did not take her as a serious candidate, but this also was a wrong assessment. Babariko and Tsepkalo's staff (led by Babariko's campaign manager Maria Kolesnikova and Tsepkalo's wife Veronika) immediately rallied behind Tikhanovskaya, and soon did the majority of now extremely anti-Lukashenko oriented people (Zahorski, 2020, p. 3; Racz, 2020, p. 2). Independent exit polls on the election-day in August showed an overwhelming victory for Tikhanovskaya (75 to 80 percent of the votes, while Lukashenko got 13 to 18), but the official results were 'standard' - 81:8 percent in favour of Lukashenko (Zahorski, 2020, pp. 16-17).

Once the official 'results' were announced, huge crowds of people got to the streets, carrying white-red-white flags, shouting anti-Lukashenko slogans and getting beaten by the police in what Sergey Tikhanovsky called 'anti-cockroach revolution'. At the moment of writing, these mostly peaceful protests but more massive than ever, spread all over Belarus, and followed by industrial workers' strikes, have been ongoing for several months (Racz, 2020, p. 1; Racz et al., 2020, pp. 2-3; Challis, 2020, p. 1). The political outcome is not yet in sight, with a new wave of the regime's repression forced Tikhanovskaya to flee to Lithuania, while Kolesnikova joined the ranks of the arrested opposition leaders. The 'honeymoon' between Lukashenko and the West is certainly over - the US and the EU refused to recognize the outcome of the elections and imposed new sanctions (Racz et al., 2020, p. 4). ${ }^{6}$ On the other hand, Russia (although maybe somewhat surprised by the quantity and the persistence of the protests) seems to get what it wanted -

${ }^{6}$ This makes the situation in Belarus comparable with the presidential crisis in Venezuela, but with one important difference - unlike Venezuela's Juan Guaido, Tikhanovskaya is not recognized as a legitimate president by any Western country (with exception of Lithuania); her election victory cannot be determined for certain (Dobrinsky, 2020, pp. 10-11). 
extremely weakened Lukashenko, who is now ready to accept any Moscow's ultimatum in return for its help to keep him afloat (Racz et al., 2020, pp. 3-4).

In short, what new to the Belarusian issue in the context of Belarusian domestic and wider European affairs does the presidential crisis 2020 bring? As already said, the social contract between Lukashenko and the Belarusian people is broken, due to economic setbacks and (in the eyes of the people) poor handling of the corona crisis. Lukashenko's days are most probably numbered - he can thrive for some more time relying on force and conditional Russian help, but some kind of transition is inevitable. It is not certain this transition would lead to real democracy in Belarus, but at least its political life could become more pluralistic. Belarus remains a country with a weak national identity - carrying disputed national symbols as fashion items still do not make most of the protesters more nationally aware. Some of the opposition leaders (including Tikhanovskaya) indeed look for support in the West, but none of them advised cutting ties with Russia. On the contrary, Babariko and Tsepkalo are closely connected to Moscow. ${ }^{7}$ The West is too passive compared to Russia, and the protesters are really much aware that the Maidan-style revolution could bring more harm than benefit to them, like it did in neighbouring Ukraine. All this does not mean there is an easy way out of the crisis; if there was, writing about the Belarusian issue would not be as challenging as it is.

\section{CONCLUSION}

So, what is the essence of the Belarusian issue in European affairs? It certainly has a geopolitical dimension - the country is situated at the very geographical centre of Europe (if it is considered as a continent that stretches from the Atlantic to the Urals). As such, it has always been some kind of a 'highway' of the continent, but also its 'doormat' over which antagonistic powers from both west and east regularly stepped during their conflicts over European mastery (at the current epoch, these powers are, of course, Russia and political West - the US, the EU and its most powerful members, NATO) (Wilson, 2011, pp. 136-137). Yet, it is not only about geopolitics, but also identity. Countries with a similar geopolitical position, such as Finland, Poland or Baltic states, have a strong and united feeling of national identity ${ }^{7}$ There was also an incident at the end of July when more than thirty Russia-based
Wagner contractors were arrested in Belarus (Racz, 2020, p. 3). 
and awareness of belonging. On the other hand, Ukrainian identity is sharply divided between those in favour of belonging to the West and those who consider themselves a part of the Russian world (Trapara, 2014, p. 36). Neither of these two is true for Belarus, whose historical development left it with a weak national identity, closely attached to Russia, but with an undeniable five-century long tradition of belonging to a distinct Western polity and its cultural influence. Hand-in-hand with this goes the mentality of the Belarusian people who prefer political stability and personal safety and well-being to democracy and a stronger national identity. An average Belarusian looks for Batka, a paternalistic leader who would provide him with his basic needs - the function successfully performed by Lukashenko for a quarter of a century.

Moreover, the affinity of the Belarusian people towards foreign powers also seems to be affected by their basic needs. As long as Russia is providing subsidies for the Belarusian economy and ensures the living standards of its people, they do not see the need to resist closer integration with its Eastern neighbour. But if and when Russia's ability and/or willingness to continue this arrangement comes into question, the temptation of Belarusians - who never doubted in their unambiguous belonging to Europe - to turn the other way becomes natural. However, their reluctance to make such a turn is also natural given their mentioned troublesome history, for they would not like to become the first line of defence of the West against their Russian brethren - the same way they refused to play Russia's first line of defence against the West during recent Lukashenko years (Wilson, 2011, pp. 138-139). And the third option, however it may be natural for a country of such geopolitical position - acting as a mediator between the East and the West, which Lukashenko actually tried to achieve - is unlikely to be successful, given the asymmetry in power between Belarus and the powers in question, as well as the bitterness of their confrontation. ${ }^{8}$ Thus, we may conclude that - although it certainly has Belarusian domestic societal roots - the Belarusian issue in European affairs is actually an image of the divisive state of these affairs in general. Rather than expecting that Belarus could overcome the problem with its self (no matter how big the energy of the protesters on its cities' streets is) to help Europe unite, the more pessimistic version is probably true - without overcoming the conflict between European Eastern and Western self and other, possible post-Lukashenko consolidation will be yet another 'false start' for Belarus.

${ }^{8}$ U.S.-Russian confrontation could actually even get worse after Joseph Biden's victory in U.S. presidential elections. 


\section{REFERENCES}

Astapenia, R. \& Balkunets, D. (2016, August 1). Belarus-Russia Relations after the Ukraine Conflict, retrieved from http:/ / belaruspolicy.com/ sites/default/files/articles/21.09.2016/belarus-russia-relations_en.pdf. Accessed 15 November 2020.

Challis, B. (2020, August). Belarus beyond 2020: Implications for Russia and the West, retrieved from https:/ / www.europeanleadershipnetwork. org /wp-content/uploads/2020/07/Belarus-policy-brief-1.pdf. Accessed 17 November 2020.

Crabtree, C., Fariss, C. J. \& Schuler, P. (2016). The presidential elections in Belarus, Electoral Studies, pp. 1-4. doi: 10.1016/j.electstud.2016.02.006

Dobrinsky, R. (2020, September). What Can Be the Way Out of the Impasse in Belarus?, retrieved from https://wiiw.ac.at/what-can-be-the-wayout-of-the-impasse-in-belarus-dlp-5392.pdf. Accessed 17 November 2020.

Ioffe, G. (2014). Reassessing Lukashenka: Belarus in Cultural and Geopolitical Context. UK, Palgrave Macmillan.

Klysinski, A. (2017, September). Double Reality. The Russian Information Campaign Towards Belarus. Russian Analytical Digest, 206, retrieved from https://css.ethz.ch/content/dam/ethz/special-interest/gess/ cis/center-for-securities-studies/pdfs/RAD206\%20\%28002\% 29.pdf. Accessed 15 November 2020.

Kuleszewicz, A. (2016). External and Internal Policies of Belarus after Crimea Annexation, Polish Political Science Review, 4(1), pp. 33-43.

Lanoszka, A. (2017). The Belarus Factor in European Security, Parameters, 47(4), pp. 75-84.

Leukavets, A. (2017, September). Belarus-Russia Relations in 2017: Behind the Curtain of the Long-lasting Drama. Russian Analytical Digest, 206, retrieved from https://css.ethz.ch/content/dam/ethz/special-interest/ gess/cis/center-for-securities-studies/pdfs/RAD206 $\% 20 \% 28002$ \%29.pdf. Accessed 15 November 2020.

Marples, D. R. (2012). Belarus: A Denationalized Nation. London and New York, Routledge.

Nizhnikau, R. \& Moshes, A. (2020). Belarus in search of a new foreign policy: why is it so difficult?, in: K. Fischer and H. Mouritzen (Eds.), Danish Foreign Policy Review (pp. 48-72). Copenhagen, Danish Institute for International Studies. 
Racz, A. (2020, August). Presidential Elections in Belarus: Tensions Are Likely to Prevail, retrieved from https://www.ssoar.info/ssoar/ bitstream/handle/document/69227/ssoar-2020-racz-Presidential_ Election_in_Belarus_Tensions.pdf?sequence $=1 \&$ isAllowed $=y \&$ Inkname =ssoar-2020-racz-Presidential_Election_in_Belarus_Tensions.pdf. Accessed 17 November 2020.

Racz, A., Gherasimov, C. \& Nič, M. (2020, August). Four Scenarios for the Crisis in Belarus, retrieved from https://www.ssoar.info/ssoar/ bitstream/handle/document/69725/ssoar-2020-racz_et_al-Four_ Scenarios_for_the_Crisis.pdf?sequence $=1 \&$ isAllowed $=y \& \ln k$ name $=$ sso ar-2020-racz_et_al-Four_Scenarios_for_the_Crisis.pdf. Accessed 17 November 2020.

Suzdaltsev, A. (2020). Crisis of the Union State of Russia and Belarus, Social Sciences, 51(2), pp. 68-83.

Trapara, V. (2014). Savremeni značaj Makinderovog koncepta Istočne Evrope: slučaj ukrajinske krize [Contemporary Significance of Mackinder's East Europe Concept: The Case of the Ukrainian Crisis], Medunarodna politika, 65(1155-1156), pp. 26-43.

Trapara, V. (2020). Ratovi Rusije 1999-2019 [Russia's Wars 1999-2019]. Belgrade, Institute of International Politics and Economics.

Wilson, A. (2011). Belarus: The Last European Dictatorship. London, Yale University Press.

Wilson, A. (2016). Belarus: from a Social Contract to a Security Contract?, The Journal of Belarusian Studies, 8(1), pp. 78-91.

Zahorski, A. (2020, September 14). Multilevel regression with poststratification for the national level Viber/Street poll on the 2020 presidential elections in Belarus, retrieved from https://arxiv.org/ pdf/2009.06615.pdf. Accessed 17 November 2020. 